\title{
Felipe Gómez Gutiérrez y María del Carmen Saldarriaga, eds. Evelio Rosero y los ciclos de la creación literaria
}

\author{
Bogotá: Editorial Pontificia Universidad Javeriana, 2017, 272 pp. \\ ISBN: 978-958-781-063-9
}

\section{Yoanny Sanabria Vergara / Universidad Distrital Francisco José de Caldas}

La crítica literaria es una práctica cultural que ayuda a consolidar y a canonizar las obras y sus autores. Las reflexiones y las discusiones que una obra genera entre sus lectores completan el círculo de la creación literaria, al tiempo que la justifican y la legitiman en el campo literario. En este horizonte podemos situar el libro que editan Felipe Gómez Gutiérrez y María del Carmen Saldarriaga sobre la obra de Evelio José Rosero. Se trata de una colección de ensayos que busca repensar toda la obra del escritor colombiano y corregir el aparente silencio del público frente a ésta. El título nos anticipa el criterio editorial, pues se piensa la obra como ciclos creativos en torno a símbolos, temas e imágenes que persisten en Rosero. Los ensayos están organizados entorno a cuatro ejes de interés provocados por la escritura del autor. Los editores abren el texto con una entrevista a Rosero en la que reflexiona sobre el sentido de la escritura en la contemporaneidad.

$\mathrm{Al}$ comienzo aparecen textos que proponen categorías de análisis para delimitar las búsquedas estéticas y las formas de representación en Rosero. Aunque por momentos los críticos caen en la trampa de sobreponer las categorías a la obra, se logran explicaciones profundas. Se acude a conceptos como el de espectro de J. Derrida para observar cómo las estrategias narrativas del autor en En el Lejero (2003) construyen un mundo de pesadilla que le da contornos estéticos al tema de la desaparición. Un estudio muestra cómo a partir de la reinvención de elementos góticos en Los Almuerzos (2001), Rosero produce una atmósfera de truculencias y abyecciones para tratar las historias femeninas del desarraigo.

Otro ensayo hace una arqueología de la enfermedad en novelas de Rosero para analizar cómo el malestar de los personajes socava sus interacciones con el cuerpo individual y social. Aquí, los signos de la enfermedad y los inventarios anatómicos representan la desmembración y la disfunción de los cuerpos en la narrativa. Al final de esta sección se estudia una faceta poco conocida de Rosero: la de poeta. Se analiza el poemario Lunas de Chía (2004) usando el significado del flâneur para explicar la mirada periférica, lo marginal y la soledad en la urbe postindustrial. Esta categoría permite observar cómo en Rosero triunfa la individualización de seres aislados, quienes están al asecho de experiencias como el voyerismo para poder conectarse con el exterior.
En la segunda parte del libro se analiza la relación entre historia y ficción en la narrativa y sus repercusiones en el estilo de Rosero. El primer ensayo se observa la función de la historia y la memoria en La carroza de Bolívar (2012), siguiendo una perspectiva sociocultural para cuestionar la tipología de esta novela. Se concluye que la de Rosero no obedece al tipo de novela histórica decimonónica, pues incorpora elementos populares de la tradición oral a través de una carnavalización de la memoria.

También se explora la reconstrucción de la memoria en Los ejércitos (2007) y La carroza de Bolivar, a través de la simbología de los nombres y de la relación que sostienen los protagonistas con el mundo femenino. En el último ensayo de esta sección se aborda la cuestión de la reinscripción de la historia, para explicar la necesidad de Rosero de contar el presente cercano por medio de una reconsideración de fragmentos de la historia. Rosero buscaría propiciar interpretaciones distintas de eventos ya contados por la historia oficial y por la tradición literaria.

En una tercera unidad se reúnen textos que vuelven sobre Los ejércitos, tal vez la novela más conocida de Rosero. En el primero se torna al tema de una narrativa fantasmal en la representación de la violencia, arguyendo que la figura del fantasma permite a Rosero establecer conexiones entre la subjetividad, la memoria y la crisis social. Más adelante se analiza la forma en que la guerra se integra a la poética de Los ejércitos a través de las vivencias y padecimientos afectivos del protagonista, que lo llevan del erotismo a la abyección. El erotismo se observa como evasión de la violencia, mientras la abyección sería la trasgresión de ese límite. Al final se incluye un ensayo cuya enfoque enriquece los acercamientos políticos a la obra, al analizar la posición crítica que Rosero despliega en la novela frente a la concepción que se tiene del sujeto liberal en el discurso de los derechos humanos. Una narrativa testimonial permitiría la empatía entre los lectores y las víctimas, y la reflexión colectiva sobre sus derechos más allá de las narrativas mediáticas que manipulan la indignación de las audiencias.

Al final del libro aparecen dos ensayos que abordan el sentido de una "literatura transparente" en obras de Rosero catalogadas como narrativas para niños y jóvenes. En el 
primer caso la transparencia se toma como la forma en que la escritura le permite a Rosero huir de la violencia y neutralizarla a través de la fantasía y la imagen del niño. En el otro estudio la transparencia resulta ser la manera de analizar las transformaciones de la infancia al ser incorporada de forma abrupta al entorno normativo de los adultos. Este momento sería la base de las narrativas tempranas del autor agrupadas en la trilogía Primera vez, y estaría caracterizado por el descubrimiento de la sexualidad convertida en tabú.
Como se observa, el libro aporta miradas muy diversas sobre la obra de un autor que es referente de la literatura colombiana contemporánea. Los lectores podrán discutir las ideas y las posturas que aquí se exponen, incluso ponerlos en duda, pero no podrán obviar su pertinencia. En esto estriba tal vez el valor de este libro, pues encierra el deseo de críticos y editores por participar y ampliar la tradición crítica que empieza a fundarse alrededor de la obra de José Evelio Rosero. 